\title{
Contribution of Investment in Hotels in Tanzania on Income Generation: A Case of Dodoma Urban
}

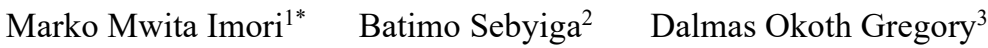 \\ 1.Local Government Training Institute (LGTI) - Hombolo, P.O Box 1125, Dodoma, Tanzania \\ 2.St. John's University of Tanzania (SJUT), Dodoma, P.O Box 47, Dodoma, Tanzania \\ 3.Local Government Training Institute (LGTI) - Hombolo, P.O Box 1125, Dodoma, Tanzania
}

\begin{abstract}
The study sought to measure the Contribution of Investment in Hotels in Tanzania on Income Generation. The study employed both quantitative and qualitative approaches under ex facto research design. Purposive sampling technique was employed to get 15 key informants such as hotel owners and managers while simple random sampling was employed to select 95 respondents of the study from hotel employees, making a total of 110 respondents. Data collected were analysed using SPSS and revealed that there is strong relationship between private investment and income generations, where by the correlation between variables tested is $89 \%$. It is recommended that the government should create good conducive environment for investment in hotels. This will help investors in generating more incomes in terms of capital and sales and as result brings economic growth through tax paid to the government.
\end{abstract}

Keywords: Business Economics, Investment Performance, Investment and Income Generation

DOI: $10.7176 / \mathrm{EJBM} / 12-11-03$

Publication date: April $30^{\text {th }} 2020$

\section{Introduction}

The hotel industry has long been considered a mirror of the economy. In other words, it has a close relationship with the economy. For example, during the period of 1993 to 2000, a phenomenal growth in the economy in the United States (U.S) provided a catalyst for the development of luxurious hotels in many regions (Jang \& Yu, 2002). Hotels are one of the private investments in the services sector and can have a significantly higher development impact when compared to other industries (Word Bank, 2007. This impact is evidenced in direct and indirect jobs, income generation, a variety of taxes, and public good dimensions, such as, encouraging infrastructure development, enhancing the image of a country, and contributing to environmental conservation. In 2007, a World Bank study looked at two large hotels (one four-star and one five-star, both operated by Sun International) in Livingstone, Zambia and concluded that the 380 rooms directly employed 840 (2.2 per room), were responsible for 60,000 tourists coming to Zambia in 2006 , provided the government with $\$ 8$ million in direct revenue from taxes, visa fees, and park fees, and spent $\$ 4$ million in the local economy. That $\$ 4$ million generated another 400 jobs, of which over 300 went to women, and paid for nearly 1,000 children to attend school (Word Bank, 2007). The hotel industry is also a significant part of the income generation worldwide and it contributes to the improvement of peoples' life standard. Excellent service provided in hotels by employees can create lasting positive experiences for customers and generate more income both to employers and employees (Morgan, 2010). In a world where government resources and charitable donations are insufficient to address the worlds social problems, private investments including investment in hotel industry offers a new alternative for channeling largescale private capital for social benefit (Morgan, 2010). Sustained private investment and a well-developed private sector in developing countries can result in increased employment, lower costs and provide access to higher quality goods and services (Hisrich, 2005).

For years, the Government of Tanzania has been adopting various measures for economic development through fiscal and monetary policies. In the early 1980's, Tanzania's economy was not doing well in many sectors including industries. Under these economic changes the Government initiated private sector development through liberalization of the economy, market decontrolling measures, etc (Kirumba, 2000). The Central Government has pulled out from most of the productive activities, and instead the private sector is encouraged to invest in these activities, the measures that brought about the emergence of micro and small enterprises. Private investment has significant contribution on income generation. More than $95 \%$ of businesses in Tanzania are small enterprises. Together, they contribute about $35 \%$ of the country Gross domestic Product (GDP). There are currently in excess of a million entrepreneurs in Tanzania running Small, Medium or Micro Enterprises (SMME's) responsible for generating up to $40 \%$ of total employment including investment in Hotel industry (TIC, 2008).

However; there is an acute shortage of studies conducted or no enough empirical evidence in Tanzania analysing the contribution of private investments specifically from hotels on income generation. This study is deemed to fill the gaps by analysing the current situation of the private investment to measure the relationship between private investment in Hotels and income generation in Dodoma Urban. 


\subsection{Methods and Materials}

The study was conducted in Dodoma District. The district is one of the seven Districts of Dodoma Region. In the recent years, the town has been growing rapidly due to the establishment of universities like the St John's University of Tanzania and the University of Dodoma (UDOM). UDOM alone has a capacity of 40,000 students. Both universities were officially established in 2007 . Not only had the establishment of those universities but also the renouncement of Dodoma as a City status and Capital City of Tanzania in April 26, 2018, changed the composition of the population in Dodoma. It has now become a political town housing the Parliament and the same time an educational and Commercial City.

\subsection{Study Population}

In Dodoma town it is estimated that employees in hotel were about 1,850 and thus the population was used as the total population size for this study, from which sample size was selected.

Out of the total population the study focused on a sample size of 95 questionnaires to hotel employees in the hotel investment sector in the Dodoma Urban. This sample size was chosen in order to facilitate meaningful depth of analysis in light of time and resource limitations, as well as enable a sample with reasonable accuracy, to reflect the opinions, attitudes and behaviour of the entire population. The study population came from 15 hotel owners and managers. Therefore 110 people were involved to represent the whole study population.

\subsection{Data Collection Methods}

This study employed different methods of data collection, whereby both primary and secondary data was collected. Interviews were administered to hotel owners to collect the primary data. In addition to this method, focus group discussion was conducted in order to gather relevant additional information from employees in hotels. Documentary review were used to collect secondary data in order to supplement primary data whereby the main sources were various official documents and reports relevant to the study problem. The combination of these methods enabled collection of adequate quantitative and qualitative data for triangulation and analysis process (Best and Kahn, 2006).

\subsection{Model of Analysis}

A multivariate regression model has been used to predict the outcome of a dependent variable with a variety of predictors or independent variables. With regard to this study, it was established in order to find the relationships that exist between private investment and income generations. In this study, the multiple regression models are in the form:

$\mathrm{Y}=\mathrm{b}_{0}+\mathrm{b}_{1} \mathrm{x}_{1}+\mathrm{b}_{2} \mathrm{x}_{2}+\mathrm{b}_{3} \mathrm{x}_{3}+. . \mathrm{b}_{\mathrm{n}} \mathrm{x}_{\mathrm{n}}+\mathrm{e}$

Where by the $\mathrm{b}$ coefficients and the constant are used to create the prediction (regression) equation and $\mathrm{Y}$ is the dependent variable.

In this study model income generation is the dependent variable with more than one independent variable or explanatory variables. The independent variables include type of investment, employment level, capital injected at the commencement of the business and education level of hotel managers. Thus, the multiple regression model in this study is as follows

Income generation $=b o+b 1($ Type of investment $)+b 2($ Employment level $)+b 3($ Initial Capital employed $)+$ $\mathrm{b} 4$ (Education level of managers) $+\mathrm{e}$. where e is the un expected issues into the hotel investment.

\subsection{Data Analysis}

Data was analyzed at 95 percent and 99 percent levels of significant. The sample size of 110 customers was drawn from total population. Statistical package for social sciences (SPSS) was used to make the analysis and to test the hypotheses stated.The quantitative interpretations were done using descriptive statistical tools like percentages, frequency distribution tables, histograms and charts. Also, inferential statistics, such as cross tabulation, chi-square and Pearson correlation coefficient was further used for analyses in this study.

\section{Results and Discussions}

\subsection{Relationship between Investment Type and Income for Employees}

The result in Table 1 below shows the relationship between the investment type and the monthly income. The type of investment of the business and the monthly income are cross tabulated and represented in the Table 1 below. The result indicate that most of the employees in both hotel and lodge their earning were ranging below Tshs 200,000 and between Tshs 200,000-300,000. This is evidenced by 24 employees and 18 employees for hotel and lodge respectively their monthly income was below Tshs 200,000, 22 employees and 10 employees for hotel and lodges respectively their monthly income was between Tshs 200,000-300,000. The findings also indicate that very few people their monthly income is Tshs 500,000 and above. However the result shows that hotel employees were paid higher compared to those working in lodge. 
Table 1: Type of investment and Monthly Earning Cross Tabulation

\begin{tabular}{cccccc}
\hline \multicolumn{7}{c}{ Monthly Earning (Income) in Tshs } \\
\hline Type of & Below 200,000 & $200,000-300,000$ & $300,000-500,000$ & 500,000 and & Total \\
investment & 24 & 22 & 12 & 4 & $\mathbf{6 2}$ \\
Hotel & 18 & 10 & 4 & 1 & $\mathbf{3 3}$ \\
Lodge & $\mathbf{4 2}$ & $\mathbf{3 2}$ & $\mathbf{1 6}$ & $\mathbf{5}$ & $\mathbf{9 5}$ \\
\hline Total & &
\end{tabular}

\subsection{Estimated Value of Initial Capital at Start of the Business and at Period of the Study}

Looking at the value of initial capital of the business at commencement, it can be seen from Table 2 below that, $1(6.7 \%)$ of the hotel owner started their business with an amount that was below Tshs $100,000,000,9(60 \%)$ started their business with amount between Tshs 100,000,000-300,000,000, 5(33.3\%) of them started their business with amount between Tshs 300,000,000-500,000,000, no one of them had the estimated capital between Tshs $500,000,000$ and above. On the other hand, $2(13.3 \%)$ of the hotel owner their capital had grown to Tshs $100,000,000-300,000,000,7(46.7 \%)$ of them had their present capital stood at Tshs 300,000,000-500,000,000, while $6(40 \%)$ of them had 500,000,000 and above as their capital at close. Thus the result indicates that there was an increase of current capital and hence more incomes for hotel owners.

Table 2: Estimated Value of Initial Capital at the Commencement of the Business and at Period of the Study

\begin{tabular}{|c|c|c|c|c|c|}
\hline \multicolumn{3}{|c|}{ Initial Capital at the Commencement } & \multicolumn{3}{|c|}{ Capital at Present Study Period } \\
\hline $\begin{array}{c}\text { Variables } \\
\text { Tshs }\end{array}$ & $\begin{array}{l}\text { Frequency } \\
n=15\end{array}$ & $\begin{array}{c}\text { Percent } \\
(\%)\end{array}$ & $\begin{array}{c}\text { Variables } \\
\text { Tshs }\end{array}$ & $\begin{array}{c}\text { Frequency } \\
n=15\end{array}$ & $\begin{array}{c}\text { Percent } \\
(\%)\end{array}$ \\
\hline Below $100,000,000$ & 1 & 6.7 & Below $100,000,000$ & 00 & 00 \\
\hline $100,000,000-300,000,000$ & 9 & 60 & $100,000,000-300,000,000$ & 2 & 13.3 \\
\hline $300,000,000-500,000,000$ & 5 & 33.3 & $300,000,000-500,000,000$ & 7 & 46.7 \\
\hline $500,000,000$ and above & 0 & 00 & $500,000,000$ and above & 6 & 40.0 \\
\hline Total & 15 & 100 & Total & 15 & 100 \\
\hline
\end{tabular}

The estimates of initial capital of the business and the current capital were cross tabulated and represented in the Figure 1 below. The figure shows that hotel owner that started with below Tshs 100,000,000 and those who had Tshs 100,000,000-300,000,000 as capital at present time of the study decreased tremendously. However the capital continued to rise but not at high rate as expected. This is shown as in Figure 1 below:

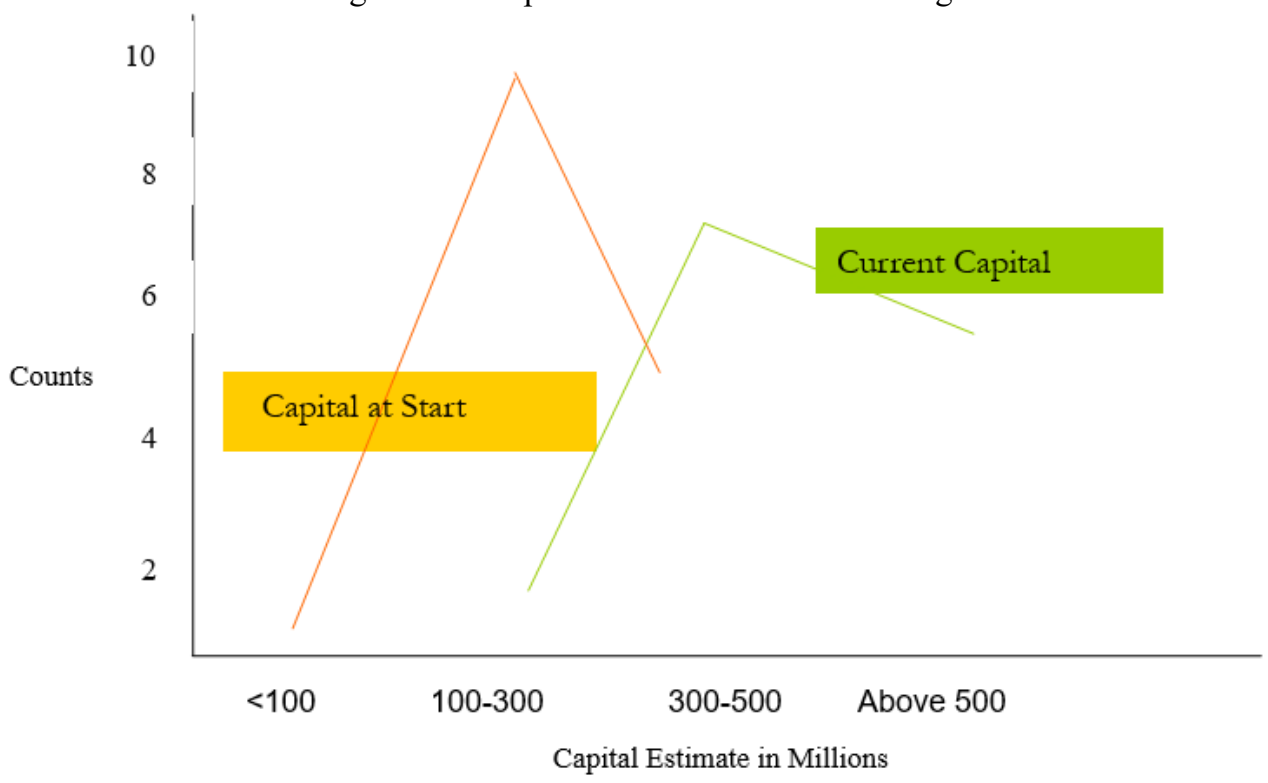

Figure 1: Estimate of Initial capital Vs. Current Capital Cross Tabulation

More over; the Pearson Chi-Square value (17.778) in Table 3 below and its significance $(0.001, p<0.05)$ indicates that there is significant difference between the estimated value of initial capital at the commencement of the business and capital at present. Accordingly, given the number of initial capital at the commencement and capital at present and the frequency of respondents reported, there is difference that would have been expected which shows that capital of the hotel owner had increased, thus generate more income. This argument is similar to study done by (Okafor, 2009) and portray that capital in the business tend to increase as time goes compared to the initial capital at the commencement of the business. 
Table3: Chi - Square Tests for Initial and Current Capital

\begin{tabular}{lccc}
\hline & Value & Df & Asymp. Sig. (2-sided) \\
\hline Pearson Chi-Square & $17.778^{\mathrm{a}}$ & 4 & .001 \\
Likelihood Ratio & 17.418 & 4 & .002 \\
Linear-by-Linear Association & 9.962 & 1 & .002 \\
\hline N of Valid Cases & $\mathbf{1 5}$ & & \\
\hline
\end{tabular}

a. 9 cells $(100.0 \%)$ have expected count less than 5 . The minimum expected count is .13.

\subsection{Estimated Value of Initial Monthly Sales at Start of the Business and at the Period of Study}

Looking at the value of initial monthly sales of the business at commencement, it can be seen from Table 4 below that, 5(33.3\%) of the hotel owner had initial monthly sales of Tshs below 20,000,000,6(40\%) had initial monthly sales between Tshs 20,000,000-50,000,000, 4(26.7\%) of them had initial monthly sales between Tshs 50,000,000$100,000,000$ and no one of them had monthly sales between Tshs 500,000,000 and above. On the other hand, $3(20 \%)$ of the hotel owner their monthly sales had increased to Tshs $20,000,000-50,000,000,8(53.3 \%)$ had their current monthly sales ranging between Tshs 50,000,000-100,000,000, while 4(26.7\%) of them had monthly sales between Tshs 100,000,000 and above.

Table 4: Estimated Value of Initial Monthly Sales at the Commencement of the Business and at Study Period

\begin{tabular}{cccccc}
\hline \multicolumn{2}{c}{ Initial Monthly Sales at the Commencement } & \multicolumn{3}{c}{ Monthly Sales at Present Study Period } \\
\hline $\begin{array}{c}\text { Variables } \\
\text { Tshs }\end{array}$ & $\begin{array}{c}\text { Frequency } \\
\mathbf{n = 1 5}\end{array}$ & $\begin{array}{c}\text { Percent } \\
\mathbf{( \% )}\end{array}$ & $\begin{array}{c}\text { Variables } \\
\text { Tshs }\end{array}$ & $\begin{array}{c}\text { Frequency } \\
\mathbf{n = 1 5}\end{array}$ & $\begin{array}{c}\text { Percent } \\
(\mathbf{\%})\end{array}$ \\
Below 20,000,000 & 5 & 33.3 & Below 20,000,000 & 00 & 00 \\
$20,000,000-50,000,000$ & 6 & 40 & $20,000,000-50,000,000$ & 3 & 20 \\
$50,000,000-100,000,000$ & 4 & 26.7 & $50,000,000-100,000,000$ & 8 & 53.3 \\
$100,000,000$ and above & 0 & 00 & $100,000,000$ and above & 4 & 26.7 \\
\hline Total & $\mathbf{1 5}$ & $\mathbf{1 0 0}$ & Total & $\mathbf{1 5}$ & $\mathbf{1 0 0}$ \\
\hline
\end{tabular}

The estimates of initial monthly sales of the business and the current monthly sales are also cross tabulated and represented in the Figure 2 below. The figure shows that hotel owner who started with monthly sales below Tshs 20,000,000 and those who had started with monthly sales between Tshs 20,000,000-50,000,000 decreased tremendously and their sales increased to monthly sales between Tshs 50,000,000-100,000,000 and Tshs $100,000,000$ and above. This is shown as in figure 2 below:

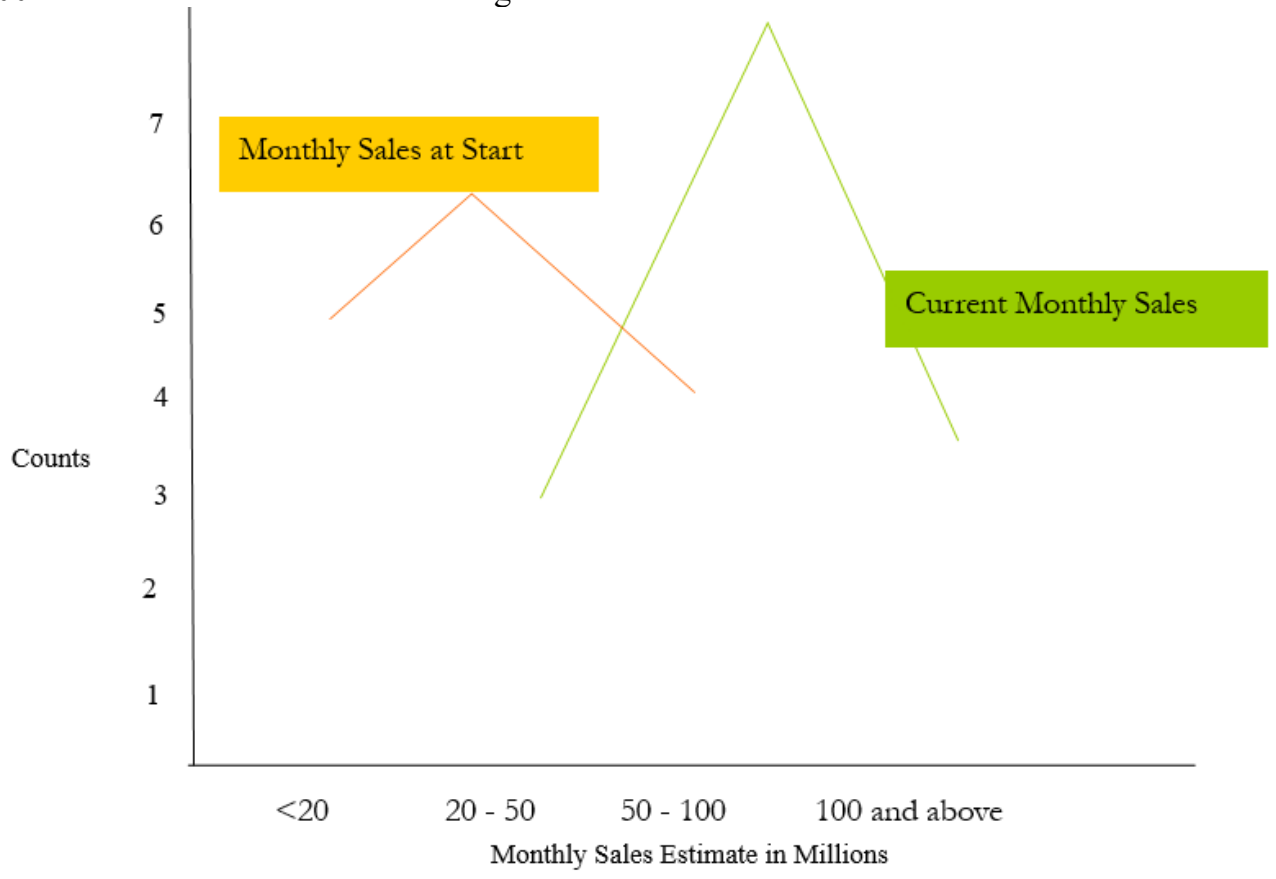

Figure2: Estimate of Initial Monthly Sales vs. Current Monthly Sales Cross Tabulation

Moreover, the Pearson Chi-Square value (21.750) in Table 5 below and its significance $(0.000, \mathrm{p}<0.05)$ indicates that there is significant difference between the estimated value of initial monthly sales at the commencement of the business and monthly sales at present. Accordingly; given the number of initial monthly sales at the commencement of the business and monthly sales at present and the frequency of behaviours reported, there is difference that would have been expected which shows that monthly sales of the hotel owner had increased, thus generate more incomes. This argument is similar to study done by (Okafor, 2009) and portray that monthly 
sales of the business tend to increased compared to the initial sales in the commencement of the business. Table 5: Chi-Square Tests for Initial and Current Monthly Sales

\begin{tabular}{lccc}
\hline & Value & Df & Asymp. Sig. (2-sided) \\
\hline Pearson Chi-Square & $21.750^{\mathrm{a}}$ & 4 & .000 \\
Likelihood Ratio & 23.558 & 4 & .000 \\
Linear-by-Linear Association & 11.288 & 1 & .001 \\
\hline N of Valid Cases & $\mathbf{1 5}$ & & \\
\hline
\end{tabular}

a. 9 cells $(100.0 \%)$ have expected count less than 5 . The minimum expected count is .80 .

\subsection{Income Generation Multivariate Regression Model}

A multivariate regression model is used to predict the outcome of a dependent variable with a variety of predictors or independent variables. With regard to this study, it was established in order to find the relationships that exist between private investment and income generations. In this study, the multiple regression model are in the form: $\mathrm{Y}=\mathrm{b}_{0}+\mathrm{b}_{1} \mathrm{x}_{1}+\mathrm{b}_{2} \mathrm{x}_{2}+\mathrm{b}_{3} \mathrm{x}_{3}+. . \mathrm{b}_{\mathrm{n}} \mathrm{x}_{\mathrm{n}}+\mathrm{e}$,

Where by the $\mathrm{b}$ coefficients and the constant are used to create the prediction (regression) equation and $\mathrm{Y}$ is the dependent variable.

In this research model income generation is the dependent variable with more than one independent variable or explanatory variables. The independent variables include type of investment, employment level, capital employed at the commencement of the business and education level of hotel managers. Thus, the multiple research regression model in this study is as follows:

Income generation $=b o+b 1($ Type of investment $)+b 2($ Employment level $)+b 3($ Initial Capital employed $)+$ b4(Education level of managers) + e.

Table 6: Regression Analysis to Show Relationship between Private Investment and Income Generations

\section{Coefficients}

\begin{tabular}{|c|c|c|c|c|c|}
\hline \multirow[b]{2}{*}{ Model } & \multicolumn{2}{|c|}{ Unstandardized Coefficients } & \multirow{2}{*}{$\begin{array}{l}\text { Standardized Coefficients } \\
\text { Beta }\end{array}$} & \multirow[b]{2}{*}{$\mathbf{t}$} & \multirow[b]{2}{*}{ Sig. } \\
\hline & B & Std. Error & & & \\
\hline (Constant) & 2.267 & 1.182 & & 1.917 & .084 \\
\hline Investment Type & -.465 & .413 & -.322 & -1.126 & .286 \\
\hline Employment Level & .089 & .341 & .101 & .260 & .800 \\
\hline Initial Capital at Commencement & .845 & .279 & .713 & 3.033 & .013 \\
\hline Education level of Manager & -.139 & .163 & -.195 & -.852 & .414 \\
\hline
\end{tabular}

a. Dependent Variable: Income

In raw score (unstandardized) units Table 6 above, the regression equation has a y-intercept (constant) of 2.267, the investment type is -0.465 , employment level is 0.089 , Initial capital at commencement is 0.0845 and Education level of manager is -0.139 . Collecting all of this information in one equation it gives:

Income generation $=2.267-0.465$ (Type of investment $)+0.089($ Employment level $)+0.0845($ Initial Capital employed)-0.139(Education level of managers) $+\mathrm{e}$.

Table 6 above indicates that the intercept is 2.267 which mean that, the income generations that will be existed when the entire explanatory variables take on the value of zero (0) is Tshs 2.267 million. The coefficient of investment type is -0.465 which mean that the income generations will be decreased by 0.465 million when investment type changes by 1 unit keeping all other variables constant. The coefficient of employment level is 0.089 which mean that the income generations will be increased by Tshs 0.089 million when employment level changes by 1 person keeping all other variables constant. Also the coefficient of initial capital employed is 0.0845 which mean that the income generations will be increased by Tshs 0.0845 million when initial capital employed changes by 1 shilling keeping all other variables constant. Lastly, the coefficient of education level of hotel managers is -0.139 which mean that the income generations will be decreased by 0.139 million when education level of hotel managers changes by 1 level of education keeping all other variables constant. 
Table 7: Coefficients of Correlation between Private Investment and Income Generation

Model Summary ${ }^{\mathrm{b}}$

\begin{tabular}{|l|c|c|c|c|}
\hline Model & R & R Square & Adjusted R Square & Std. Error of the Estimate \\
\hline 1 & $.890^{\mathrm{a}}$ & .791 & .708 & .38030 \\
\hline
\end{tabular}

a. Predictors: (Constant), Education level of manager, Investment type, Initial capital at commencement, Employment level

b. Dependent Variable: Income

The magnitude of a correlation indicates how strong a relationship that exists between variables is. That is; the magnitude of the relationship between the income generations and the best linear combination of all the predictor variables that is; type of investment, employment level, capital employed at the commencement of the business and education level of hotel managers are strongly related. From Table 7 above, result indicate that, $\mathrm{R}=$ 0.89 which shows that there is strong relationship between the income generations and all the predictor variables.

On the other hand the coefficient of determination, $\mathrm{R}^{2}$ measures the proportion of the total variation in the income generations, $\mathrm{y}$ that is explained by the predictive power of all the explanatory variables, through the multiple regression models. Table 7 above further indicate that, the $\mathrm{R}^{2}$ is 0.791 which means that the $79.1 \%$ in the proportion of the total variation in income generations, $y$ is explained by the predictive powers of type of investment, employment level, capital employed at the commencement of the business and education level of hotel managers and the remaining $20.9 \%$ being explained by other variables not considered in this case. Thus; generally the study shows that there is strong relationship between private investment and income generations. This argument is similar to the findings of the study done by Chi Hung Kwan (2004) shows that in some countries there is a strong relationship between investments and income generation which leads to economic growth.

\section{Conclusions and Recommendations}

Based on the major findings, it has been revealed that private investment specifically in hotels have positive contributions to income generations mostly for hotel owners. It is noticed that, private investment in hotels also serves the poor especially employees in hotels in increasing their incomes through payment of salaries. Most of employees working in hotels were youth with the age ranging between 26-35 years most of them with low education and mainly they were female. The reason behind it is that, most of hotels employees are composed of the vulnerable group. That is females who have low access to education for many societies in Tanzania and thus most of them were employed in hotels. The major benefits of hotel investment to hotel owners is that; at the time of study period, capital and sales for hotel investment were highly increased compared to those during commencement of the business; the hotel owner who had monthly sales between Tshs 50,000,000 - Tshs $100,000,000$ at the commencement of the business was only $26.7 \%$ while at current period was $53.3 \%$. Despite the contributions of private investment in income generations especially for hotel owners and all the benefits associated with private investment in hotels, the monthly income generated by their employees in terms salary is still lower because majority of people were paid salary ranging below Tshs $200,000 /=$ and between Tshs 200,000 $-300,000 /=$ which is quite low compared to increasing cost of living in Dodoma City and other cities in the country. Based on the major research findings, the researcher recommended that the government should create good conducive environment for investment in hotels and to establish the policies that encourage and strengthen the private sector in the country. This will help investors in generating more incomes in terms of capital and sales which in turn will be beneficial to hotel owner and employees and as a result it will contribute to the growth of the economy because the more the income generated from hotel investment the more the tax will be collected by government.

\section{References}

Best, W. J., and Kahn, V. J. (2006). Research in education (10thed). Boston: Pearson.

Chi Hung Kwan, China in Transition, RIETI, 2004.

Culkin, N., and Smith, D. (2000). An Emotional Business: A Guide to Understanding the Motivations of Small Business Decision Takers. Qualitative Market Research, 3(3), 145-157

Hisrich, R.D. (2005). Entrepreneurship: New Venture creation.5th edition .Tata McGraw Hill, New Delhi.

Jang, S., \& Yu, L. (2002). Analysis of return on hotel investment: A comparison of commercial hotel companies and casino hotel companies. Journal of Hospitality\& Tourism Research, 26 (1), 38-53.

Josiane, C. (1998). Gender Issues in Micro-Enterprise Development, ILO Publications, Geneva, June. http://www.ilo.org/enterprise.

Kirumba, E. (2000). SME policies and policy formulation in SADC countries : papers presented to the workshop of the SEPAC Working Group "Policy Issues", Gaborone, September 11-12, 1997 / ed. by Jutta Franz ... Friedrich-Ebert-Stiftung, Botswana Office. - [Electronic ed.]. - Gaborone, 1998. - 98 S. = 206 Kb, Text . - 
(SEPAC workshop papers ; 1998,1). - ISBN 99912-96-3-6. Electronic ed.: Bonn: FES Library, 2000

Okafor, Chinonye (2009). Motivational Patterns of women entrepreneurs in Small and Medium Scale Enterprises: A Case Study in South-West Nigeria

Schumpeter, J. (1934). The Theory of Economic Development. Cambridge. M. A. Harvard University

Sharma, A. and Upneja, A.(2005). Factors influencing financial performance of small hotels in Tanzania, International Journal of Contemporary Hospitality Management 17 (6), p 504-515

URT, 2002. Overview of the Tourism Sector

Wang, C, Walker, E. A. and Redmond, J. (2006).Ownership Motivation and Strategic Planning in Small Business. Journal of Asia Entrepreneurship and Sustainability, Vol. 11, Issue 4. 